\title{
DUKUNGAN KELUARGA DENGAN KEPATUHAN \\ PASIEN GAGAL GINJAL KRONIK DALAM MENJALANI HEMODIALISA
}

\author{
Iwan Shalahuddin, Udin Rosidin \\ Dosen Fakultas Keperawatan UNPAD, Kampus Garut
}

\begin{abstract}
Abstrak
Hemodialisis digunakan bagi pasien dengan tahap akhir gagal ginjal atau pasien berpenyakit akut yang membutuhkan dialisis waktu singkat. Menurut Indonesian Renal Registry 2011, pasien GGK yang menjalani hemodialisa berjumlah 22.304 jiwa. Masalah besar yang berkontribusi pada kegagalan hemodialisis adalah masalah kepatuhan klien. Banyak faktor yang menyebabkan kepatuhan yang berdampak pada kegagalan klien dalam mengikuti program terapi gagal ginjal, meliputi faktor usia, jenis kelamin, pendidikan, lamanya, pengetahuan, kebiasaan merokok, motivasi, akses pelayanan kesehatan, peran persepsi pasien terhadap pelayanan perawat dan dukungan keluarga. Data tahun 2014 di RSUD dr. Slamet Garut dari 66 orang pasien yang menjalani hemodialisis ada 34 orang yang patuh dan ada 32 orang yang tidak patuh. Penelitian ini bertujuan untuk mengetahui adanya hubungan dukungan keluarga dengan kepatuhan pasien gagal ginjal kronik yang menjalani hemodialisa di Ruang Hemodialisa RSUD dr. Slamet Garut. Metode penelitian yang digunakan adalah deskriptif korelatif dengan pendekatan cross sectional. Analisa data menggunakan analisa univariat dengan rumus persentase dan analisa bivariat menggunakan spearman rank. Hasil penelitian menunjukan Sig. (2-tailed) adalah 0,003 $(\rho<0,05)$ berarti ada hubungan antara dukungan keluarga dengan kepatuhan pasien gagal ginjal kronik yang menjalani hemodialisa. Penulis menyarankan untuk membuat kelompok atau perkumpulan pasien hemodialisa dan membuat rencana tindak lanjut berupa kartu pengingat yang dilakukan setelah post hemodialisa untuk mengingatkan jadwal selanjutnya dalam memaksimalkan kepatuhan pasien dalam menjalani hemodialisa.
\end{abstract}

Kata Kunci: Dukungan keluarga, kepatuhan, gagal ginjal, hemodialisa

\begin{abstract}
Hemodialysis is used to treat the end stage renal disease patient or the patient with the chronic disease who needs the immediate dialysis. According to the Indonesian Renal Registry 2011 showed patient with chronic renal failure who conducts the hemodialysis procedure is 22.304. The big problem contribute to the hemodialysis process failure is the patients obedience. There are many factors causes the disobedience of the patients impacting the renal therapy failure, among others age, gender, educational background, duration, smoking habit, motivation, health service access, the role of patients perception towards nursing service and family support. The data taken from RSUD dr. Slamet Garut 2014 showed that 66 patients who conducts hemodialysis therapy consist of 34 obedient patients and 32 disobedient patients. This research was animed to find out the relationship between family support and chronic renal failure patients abedience who conduct the hemodialysis procedure in hemodialisa room RSUD dr. Slamet Garut. The method used descriptive correlative research method with cross sectional approach. The data analysis used the univariate analysis with percentage formula and bivariate analysis with spearman rank. The result of the research showed that Sig. (2-tailed) was 0,003 ( $\rho$ $<0,05)$, means that there is a relationship between family support and chronic renal failure patients obedience who conduct the hemodialysis procedure. There is an intended value that the researcher suggests, it is important that the patient form a group of hemodialysis patient and arrange the follow-up plan in form of reminder card implemented after post hemodialysis procedure in order to remind the next $H D$.
\end{abstract}

Keywords: Family support, obedience, renal failure, hemodialysis. 


\section{PENDAHULUAN}

Gagal Ginjal Kronik adalah suatu keadaan klinis yang ditandai dengan penurunan fungsi ginjal yang irreversibel, pada suatu derajat yang memerlukan terapi pengganti ginjal yang tetap, berupa dialysis atau transplantasi ginjal (Suwitra, 2006). Gagal Ginjal Kronik merupakan masalah kesehatan di seluruh dunia yang berdampak pada masalah medik, ekonomi, dan sosial yang sangat besar bagi pasien dan keluarganya, baik di negara-negara maju maupun di negara-negara berkembang.

Menurut survey evaluasi kesehatan dan gizi nasional tahun 2012 di Amerika Serikat, dari 100 orang dewasa, 31 orang diantaranya mengidap penyakit ginjal tahap akhir. Insiden dan prevalensi gagal ginjal kronik semakin meningkat sekitar 8 persen setiap tahunnya. Tingginya insiden penyakit ini diikuti oleh biaya yang harus ditanggung oleh pasien penyakit ginjal tahap akhir yaitu $\$ 69,758$ atau sekitar Rp.640 juta/tahun per orang. Pada tahun 2012 terdapat 1,1 juta orang menjalani dialisis kronik, dan tahun 2013 diproyeksikan lebih dari 2 juta orang akan menjalani dialysis pula (Setiawan, 2012). Berdasarkan data Depkes RI (2007) dari 10 besar kematian terbanyak penyakit tidak menular, gagal ginjal kronik berada diurutan ke-4 (3,16\%) setelah stroke $(4,87 \%)$, perdarahan intrakranial $(3,71 \%)$, septisemia (3,18\%). Sedangkan urutan kelima sampai ke sepuluh yaitu penyakit jantung (2,67\%), diabetes mellitus $(2,16 \%)$, hipoksia intrauterus (1,95\%), radang susunan saraf $(1,86 \%)$, gagal jantung $(1,77 \%)$ dan hipertensi $(1,62 \%)$.

Berdasarkan Pusat Data \& Informasi Perhimpunan Rumah Sakit Seluruh Indonesia, jumlah pasien gagal ginjal kronik diperkirakan sekitar 50 orang per satu juta penduduk, $60 \%$ adalah usia dewasa dan usia lanjut. Menurut Depkes RI 2013 di Provinsi Jawa Barat dan Banten pada tahun 2013 tercatat 2.260 kasus penderita gagal ginjal (Profil Kesehatan Propinsi Jawa Barat dan Banten, 2013). Data dari Dinas Kesehatan Kabupaten Garut, menunjukan penderita penyakit gagal ginjal pada tahun
2013 tercatat berjumlah 149 orang dan diantaranya adalah yang menjalani hemodialisis di Ruang Hemodialisa RSU dr. Slamet Garut.

Hemodialisis (HD) adalah proses pembersihan darah oleh akumulasi sampah buangan. Hemodialisis digunakan bagi pasien dengan tahap akhir gagal ginjal atau pasien berpenyakit akut yang membutuhkan dialisis waktu singkat (Nursalam, 2006). Sedangkan (Kim, 2010) berpendapat bahwa hemodialisis merupakan salah satu terapi pengganti ginjal (TPG) yang paling umum dijalani oleh pasien gagal ginjal kronik.

Masalah besar yang berkontribusi pada kegagalan hemodialisis adalah masalah kepatuhan klien (Kamerrer, 2007 dalam Syamsiah, 2011). Secara umum kepatuhan (adherence) didefinisikan sebagai tingkatan perilaku seseorang yang tertuju terhadap intruksi atau petunjuk yang diberikan dalam bentuk terapi apapun yang ditentukan baik itu jadwal pengobatan, mengikuti diet, dan atau melaksanakan perubahan gaya hidup sesuai dengan rekomendasi pemberi pelayanan kesehatan (WHO, 2006). Kepatuhan pasien terhadap rekomendasi dan perawatan dari pemberi pelayanan kesehatan adalah penting untuk kesuksesan suatu intervensi. Ketidakpatuhan menjadi masalah yang besar terutama pada pasien yang menjalani hemodialisis.

Banyak faktor yang menyebabkan kepatuhan yang berdampak pada kegagalan klien dalam mengikuti program terapi gagal ginjal meliputi faktor usia, jenis kelamin, pendidikan, lamanya HD, pengetahuan tentang HD, kebiasaan merokok, motivasi, akses pelayanan kesehatan, peran persepsi pasien terhadap pelayanan perawat dan dukungan keluarga (Kamerrer, 2007 dalam Syamsiah, 2011).

Upaya pencegahan dan penanggulangan tidak dapat dilakukan hanya oleh pemerintah saja tetapi harus dibantu oleh semua pihak baik masyarakat maupun profesi yang terkait, khususnya tenaga kesehatan. Perawat sebagai salah satu profesi kesehatan memiliki peran yang 
sangat besar karena memiliki waktu interaksi terlama dengan pasien di institusi kesehatan, khususnya dalam memberikan informasi yang penting untuk meningkatkan kepatuhan pasien. Selain peran perawat, peran yang sangat penting dalam penatalaksanaan kepatuhan pasien untuk melakukan hemodialisa yaitu dukungan keluarga.

Berdasarkan data yang diperoleh dari Register Ruang Hemodialisa RSUD dr. Slamet Garut, Jumlah pasien hemodialisis yang terjadwal dalam kegiatan hemodialisa dengan frekuensi kunjungan 2 kali dalam seminggu (pasien rutin) sejak bulan Januari sampai bulan Oktober 2014 adalah 66 orang. Selanjutnya dari data registrasi harian Ruang Hemodialisa bahwa dari 66 orang pasien hemodialisa ada 32 orang yang patuh dan ada 34 orang yang tidak patuh sesuai jadwal hemodialisa selama periode bulan Januari - Oktober 2014.

Berdasarkan studi pendahuluan melalui wawancara yang dilakukan oleh peneliti terhadap pasien gagal ginjal kronik yang menjalani hemodiaisa di Ruang Hemodialiasa RSUD dr. Slamet Garut dari 10 orang pasien didapat keterangan bahwa ada 5 orang (50\%) yang sesuai jadwal dan 5 orang $(50 \%)$ yang tidak sesuai jadwal. Dari 5 orang yang sesuai jadwal 3 orang (60\%) mendapat dukungan keluarga yang baik yaitu keluarganya selalu mengingatkan jadwal cuci darah, suka memberikan support, suka menyiapkan biaya untuk cuci darah bahkan suka diantar oleh keluarganya setiap cuci darah, dan 2 orang (40\%) mendapatkan dukungan keluarga yang kurang yaitu keluarganya tidak mengingatkan jadwal cuci darah, kurang memberikan motivasi, keluarga kurang siap jika dibutuhkan untuk mengantar ketika cuci darah. Sedangkan dari 5 orang yang tidak sesuai jadwal, seluruhnya (100\%) mendapatkan dukungan keluarga yang kurang yaitu keluarganya tidak mengingatkan jadwal cuci darah, kurang memberikan motivasi, keluarga kurang siap jika dibutuhkan untuk mengantar ketika cuci darah dan akhirnya datang terlambat ketika mau cuci darah karena harus menunggu dulu keluarganya pulang kerja dan bahkan tidak mengantarkanya sama sekali setiap mau cuci darah. Dari 10 orang pasien, ada 6 orang $(60 \%)$ yang diantar oleh keluarganya dan 4 orang $(40 \%)$ tidak diantar oleh kelurganya.

Berdasarkan latar belakang di atas, maka penulis dapat merumuskan masalah sebagai berikut "Adakah Hubungan Dukungan Keluarga dengan Kepatuhan Pasien Gagal Ginjal Kronik yang Menjalani Hemodialisa di Ruang Hemodialisa RSUD dr. Slamet Garut".

Penelitian ini dimaksudkan untuk mengidentifikasi hubungan dukungan keluarga dengan kepatuhan pasien gagal ginjal kronik yang menjalani hemodialisa di Ruang Hemodialisa RSUD dr. Slamet Garut.

\section{METODOLOGI PENELITIAN}

Desain penelitian menggunakan rancangan deskriptif korelatif dengan pendekatan cross sectional. Penelitian ini bertujuan mendeskripsikan tentang hubungan dukungan keluarga dengan kepatuhan pasien gagal ginjal kronis yang menjalani hemodialisis di Ruang Hemodialisa RSUD dr. Slamet Garut.

Variabel pada penelitian ini mengacu pada konsep menurut Friedman 1988, dukungan keluarga adalah keikut sertaan keluarga untuk memberikan bantuan kepada salah satu anggota keluarga yang membutuhkan pertolongan baik dalam hal pemecahan masalah, pemberian keamanan dan peningkatan harga diri (Setiadi, 2008). Keluarga memiliki beberapa bentuk dukungan yaitu dukungan emosional, dukungan penghargaan, dukungan instrumental dan dukungan informasional. Sehingga Variabel terikat dalam penelitian ini adalah kepatuhan pasien GGK yang menjalani hemodialisa dan variabel bebas dalam penelitian ini adalah dukungan keluarga.

\section{HASIL PENELITIAN}

Hasil analisis univariat dan bivariate menunjukan sebagai berikut: 
Tabel 1. Distribusi Frekuensi Dukungan Keluarga Pasien Gagal Ginjal Kronik

\begin{tabular}{lcc}
\hline Dukungan & Frekuensi & $\begin{array}{c}\text { Presentasi } \\
(\%)\end{array}$ \\
\hline $\begin{array}{l}\text { Dukungan } \\
\text { Tinggi }\end{array}$ & 21 & 52,5 \\
\hline $\begin{array}{l}\text { Dukungan } \\
\text { Rendah }\end{array}$ & 19 & 47,5 \\
\hline Jumlah & 40 & 100 \\
\hline
\end{tabular}

Tabel 2. Distribusi Frekuensi Kepatuhan Pasien Gagal Ginjal Kronik

\begin{tabular}{rcc}
\hline Kepatuhan & Frekuensi & $\begin{array}{c}\text { Presentasi } \\
(\%)\end{array}$ \\
\hline Patuh & 26 & 65 \\
\hline $\begin{array}{r}\text { Tidak } \\
\text { Patuh }\end{array}$ & 14 & 35 \\
\hline Jumlah & 40 & 100 \\
\hline
\end{tabular}

Tabel 3. Hubungan Dukungan Keluarga dengan Kepatuhan Pasien Gagal Ginjal

Kronik yang Menjalani Hemodialisa

\begin{tabular}{lccc}
\hline \multirow{2}{*}{ Dukungan } & \multicolumn{2}{c}{ Kepatuhan } & Jumlah \\
\cline { 2 - 3 } & Patuh & $\begin{array}{c}\text { Tidak } \\
\text { Patuh }\end{array}$ & \\
\hline $\begin{array}{l}\text { Dukungan } \\
\text { Tinggi }\end{array}$ & $\begin{array}{c}19 \\
(90,5 \%)\end{array}$ & $\begin{array}{c}2 \\
(9,5 \%)\end{array}$ & $\begin{array}{c}21 \\
(100 \%)\end{array}$ \\
\hline $\begin{array}{l}\text { Dukungan } \\
\text { Rendah }\end{array}$ & 7 & 12 & 19 \\
\hline \multicolumn{1}{c}{ Jumlah } & $26,8 \%)$ & $(63,2 \%)$ & $(100 \%)$ \\
\hline
\end{tabular}

Tabel 4. Koefisien Korelasi Dukungan Keluarga dengan Kepatuhan Pasien Gagal Ginjal Kronik yang Menjalani Hemodialisa Correlations

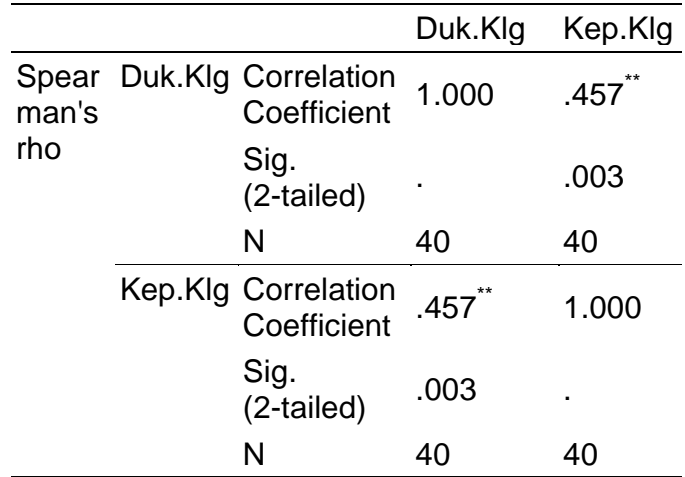

${ }^{\star *}$. Correlation is significant at the 0.01 level (2tailed).
Berdasarkan tabel di atas bahwa $\mathrm{N}$ menunjukan jumlah sampel sebanyak 40 orang. Sedangkan angka Sig. (2-tailed) adalah 0,003 , nilai ini lebih kecil daripada batas kritis $\alpha=0,05(0,003<0,05)$, berarti terdapat hubungan yang signifikan antara dukungan keluarga dengan kepatuhan. Selanjutnya nilai correlation coefficient (koefisien korelasi) ditunjukan oleh angka $0,457^{*}$, maka nilai ini menandakan ada hubungan yang tinggi antara dukungan keluarga dengan kepatuhan.

\section{PEMBAHASAN}

Hasil penelitian didukung oleh hasil penelitian Gamya (2013) didapat bahwa sebagian besar responden memiliki dukungan keluarga yang tinggi. Keluarga dapat menjadi faktor yang sangat berpengaruh dan menentukan keyakinan dan nilai kesehatan individu dan dapat juga menentukan tentang program pengobatan yang diterima. Niven (2002) menyatakan bahwa dukungan keluarga merupakan salah satu faktor yang mempengaruhi kepatuhan. Keluarga dapat membantu menghilangkan godaan pada ketidakpatuhan dan keluarga seringkali dapat menjadi kelompok pendukung untuk mencapai kepatuhan.

Banyak faktor yang menyebabkan kepatuhan yang berdampak pada kegagalan klien dalam mengikuti program terapi gagal ginjal meliputi faktor usia, jenis kelamin, pendidikan, lamanya HD, pengetahuan tentang HD, kebiasaan merokok, motivasi, akses pelayanan kesehatan, peran persepsi pasien terhadap pelayanan perawat dan dukungan keluarga (Kamerrer, 2007 dalam Syamsiah, 2011)

Keluarga merupakan faktor eksternal yang memiliki hubungan paling kuat dengan pasien. Keberadaan keluarga mampu memberikan motivasi yang sangat bermakna pada pasien disaat pasien memiliki berbagai permasalahan perubahan pola kehidupan yang demikian rumit, menjenuhkan dengan segala macam program kesehatan. Hasil penelitian ini didukung oleh penelitian Hakim (2007), hasil penelitianya membuktikan bahwa terdapat 
hubungan yang positif antara dukungan keluarga dengan meningkatnya angka kepatuhan pasien hemodialisis dengan $r=$ 0,584 and $\rho=0,003$ (Hakim, 2007).

Berdasarkan tabel diatas dapat diketahui bahwa dari indicator dukungan keluarga didapat bahwa dukungan instrumental, informasional, dan penilain sebagian besar dari responden mendapatkan dukungan keluarga rendah. Sedangkan untuk indicator dukungan emosional sebagian besar responden mendapat dukungan tinggi. Ada banyak strategi untuk meningkatkan dukungan keluarga terhadap kepatuhan khusunya untuk indicator dukungan instrumental, informasional dan penilaian adalah memperbaiki komunikasi dengan cara yang efektif antara keluarga dengan pasien ataupun dengan tim kesehatan. Memberikan informasi yang jelas kepada pasien tentang penyakitnya dan cara pengobatanya.

Tenaga kesehatan adalah orang yang berstatus tinggi bagi kebanyakan pasien dan apa yang ia katakana secara umum diterima sebagai sesuatu yang sah dan benar. Tenaga kesehatan harus mampu mempertinggi dukungan. Selain itu keluarga dilibatkan dalam memberikan dukungan kepada pasien, karena hal tersebut juga akan meningkatkan dukungan keluarga terhadap kepatuhan. Rustiana (2006) menjelaskan bahwa dukungan tersebut bias diberikan dengan bentuk perhatian dan memberikan nasehatnya yang bermanfaat bagi kesehatanya. Pendekatan perilaku pengelolaan diri (self management) yaitu bagaimana pasien diarahkan agar dapat mengelola dirinya dalam usaha meningkatkan perilaku kepatuhan. Dokter dapat bekerja sama dengan keluarga pasien untuk mendiskusikan masalah dalam menjalani kepatuhan serta pentingnya pengobatan

Berdasarkan tabel diatas dapat diketahui bahwa sebagian besar dari responden patuh. Hasil penelitian ini didukung oleh hasil penelitian Gamya (2013) didapatkan bahwa mayoritas responden patuh. Tingkat kepatuhan adalah sikap yang ditunjukkan oleh penderita GGK untuk mematuhi diet yang harus dijalani. Kepatuhan menurut Niven (2002) bahwa kepatuhan pasien adalah sejauh mana perilaku pasien sesuai dengan ketentuan yang diberikan oleh profesional kesehatan. Potter dan Perry (2006) menyatakan bahwa kepatuhan sebagai ketaatan pasien dalam melaksanakan tindakan terapi. Kepatuhan pasien berarti bahwa pasien beserta keluarga harus meluangkan waktu dalam menjalankan pengobatan yang dibutuhkan termasuk dalam manjalani hemodialisa

Definisi kepatuhan WHO cenderung menggambarkan kondisi untuk penyakit kronis sehingga sangat tepat diterapkan pada pasien hemodialisis. Bagi banyak orang dengan penyakit kronis, kepatuhan memainkan peranan penting dalam kelangsungan hidup pasien. Untuk mengelola keberhasilan penyakit kronis, individu harus bertanggung jawab dalam banyak aspek pengobatan mereka sendiri secara teratur dan jangka panjang. Sehingga untuk mewujudkan kepatuhan, pasien perlu menggabungkan perubahan gaya hidup dan perubahan perilaku lainnya menjadi rutinitas mereka sehari-hari.

Upaya pencegahan dan penanggulangan tidak dapat dilakukan hanya oleh pemerintah saja tetapi harus dibantu oleh semua pihak baik masyarakat maupun profesi yang terkait, khususnya tenaga kesehatan. Perawat sebagai salah satu profesi kesehatan memiliki peran yang sangat besar karena memiliki waktu interaksi terlama dengan pasien di institusi kesehatan, khususnya dalam memberikan informasi yang penting untuk meningkatkan kepatuhan pasien. Selain peran perawat, peran yang sangat penting dalam penatalaksanaan kepatuhan pasien untuk melakukan hemodialisa yaitu dukungan keluarga. Kebutuhan akan dukungan dan perhatian keluarga berlangsung sepanjang hidup. Melalui dukungan keluarga, pasien akan merasa masih ada yang memperhatikan. Dukungan keluarga dapat diwujudkan dengan memberikan perhatian, bersikap empati, memberikan dorongan, 
memberikan saran, memberikan pengetahuan dan sebagainya (Kamerrer, 2007 dalam Syamsiah, 2011). Hubungan Dukungan Keluarga dengan Kepatuhan Pasien Gagal Ginjal Kronik yang Menjalani Hemodialisa

Dukungan keluarga berpengaruh penting dalam pelaksanaan pengobatan berbagai jenis penyakit kronis dan dukungan keluarga sangat berpengaruh terhadap kesehatan mental anggota keluarganya. Dukungan yang dimiliki oleh seseorang dapat mencegah berkembangnya masalah akibat tekanan yang dihadapi. Seseorang dengan dukungan yang tinggi akan lebih berhasil menghadapi dan mengatasi masalahnya dibanding dengan yang tidak memiliki dukungan (Setiadi, 2008)

Penelitian ini didukung oleh penelitian yang dilakukan oleh Rini (2013) dengan judul hubungan dukungan keluarga terhadap kepatuhan pasien gagal ginjal kronik yang menjalani hemodialisa. Hasil penelitian tersebut menunjukkan bahwa dukungan social memiliki hubungan yang signifikan dengan perilaku kepatuhan. Penelitian lain yang dilakukan oleh Sari (2009) menunjukkan bahwa ada hubungan yang signifikan antara dukungan keluarga dengan kepatuhan pasien dalam menjalani hemodialisa

Dari data diatas terlihat ada kecenderungan bahwa semakin tinggi dukungan keluarga makan akan semakin tinggi angka kepatuhanya dan semakin rendah dukungan keluarga maka semakin rendah angka ketidakpatuhanya. Hasil penelitian ini didukung juga oleh hasil penelitian yang dilakukan oleh Syamsiah (2011) menunjukkan bahwa lebih banyak responden yang mendapat dukungan keluarga baik dibandingkan dengan responden yang mendapat dukungan keluarga kurang. Responden yang mendapat dukungan keluarga baik mendapat proporsi kepatuhan lebih besar dibandingkan dengan responden yang mendapat dukungan keluarga kurang baik.

Hasil uji chi-square menunjukkan $\rho$ value $0,014 \quad(\rho<0,05)$ terdapat hubungan yang bermakna antara dukungan keluarga dengan kepatuhan pasien gagal ginjal kronik yang menjalani hemodialisa. Hasil odds ratio 2,363 yang berarti responden yang mendapat dukungan keluarga baik memiliki peluang untuk lebih patuh sebesar 2,363 kali dibandingkan responden yang mendapat dukungan keluarga kurang baik.

Faktor dukungan keluarga dapat menjadi faktor yang sangat berpengaruh dalam menentukan keyakinan dan nilai serta dapat juga menentukan program pengobatan yang dapat diterima mereka. Keluarga juga member dukungan dan membuat keputusan mengenai perawatan keluarga yang sakit (Niven N, 2002 dalam Syamsiah 2011).

\section{KESIMPULAN DAN SARAN}

Sebagian besar dari responden memiliki dukungan tinggi dan hampir setengah dari responden memiliki dukungan rendah. Sebagian besar dari responden patuh dan hampir setengah dari responden tidak patuh.

Ada hubungan yang signifikan antara dukungan keluarga pasien gagal ginjal kronik yang menjalani hemodialisa dengan kepatuhan pasien gagal ginjal kronik yang menjalani hemodialisa di Ruang Hemodialisa RSUD dr. Slamet Garut Tahun 2016. Dari data tersebut terlihat ada kecenderungan bahwa semakin tinggi dukungan keluarga makan akan semakin tinggi angka kepatuhanya dan semakin rendah dukungan keluarga maka semakin rendah angka ketidakpatuhanya.

Rumah sakit diharapakan dapat membentuk kelompok pasien hemodialisa yang digunakan untuk tempat bertukar pikiran antara sesama pasien hemodialisa baik itu pasien lama ataupun pasien baru. Perawat dapat membuat rencana tindak lanjut berupa kartu pengingat yang dilakukan setelah post HD untuk mengingatkan jadwal HD selanjutnya dan memaksimalkan kepatuhan pasien HD dalam menjalani hemodialisa. 


\section{DAFTAR PUSTAKA}

Arikunto, S. (2010). Prosedur Penelitian Suatu pendekatan Praktik. Jakarta: Rineka Cipta

Brunner \& Suddart, (2002). Buku Ajar Keperawatan Medikal Bedah, Edisi 8, Vol.1. Jakarta: EGC

Dinkes Kab. Garut, (2013). Profil Kesehatan Kabupaten Garut 2012

Hidayat, (2007). Metode Penelitian. Jakarta: Pustaka Pelajar (2007). Riset Keperawatan dan

Tekhnik Penulisan IImiah. Jakarta: Salemba Medika , (2008). Metode Penelitian

Keperawatan dan Teknik Analisa Data. Jakarta: Salemba Medika

Kammerer J., Garry G., Hartigan M., Carter B., Erlich L., (2007), Adherence in Patients on Dialysis: Strategies for Succes, Nephrology Nursing Journal: Sept-Okt 2007, Vol 34, No.5, 479-485.

Kim, Y., Evangelista I.S., Phillips, L.R., Pavlish, C., \& Kopple, J.D. (2010). The End-Stage Renal Disease Adherence Questionnaire (ESRD-AQ): Testing the psychometric properties in patients receiving in-center hemodialysis. Nephrology Nursing Journal, 37 (4), 377393.

Medical Record RSU dr. Slamet Garut. Profil Kesehatan RSU dr. Slamet Garut 2014

Notoatmodjo, S. (2003). Pendidikan dan perilaku kesehatan. Jakarta: PT Rineka Cipta

Nursalam, (2006). Asuhan Keperawatan pada Pasien Dengan Gangguan Sistem Perkemihan. Jakarta: Salemba Medika

Potter, P., (2005). Fundamental Keperawatan: Konsep, Proses, dan Praktek, Vol 2. Edisi 4. Jakarta: EGC

Prince S.A, and Wilson L.M., (2006). Patofisiologi Konsep Klinis Prosesproses Penyakit. Jakarta: EGC
Profil Kesehatan Propinsi Jawa Barat dan Banten, (2013). diambil pada tanggal 17 Oktober 2014 dari: www.diskes.jabarprov.go.id

Purnawan, (2008). Konsep Keluarga. Jakarta: EGC

Rohman, (2007). Faktor-faktor yang berhubungan dengan Pemberian AsuhanSpiritual oleh Perawat di RS Islam Jakarta, Tesis, Jakarta: Universitas Indonesia

Sabri, L. \& Hastono, S.P. (2006). Statistik Kesehatan. Jakarta: PT. Raja Grafindo Persada

Setiadi, (2007). Konsep dan Penulisan Riset Keperawatan. Yoyakarta: Graha IImu (2008). Konsep dan Proses

Keperawatan Keluarga. Yoyakarta: Graha IImu

Smeltzer, S.C., Bare, B.G., Hinkle, J.L., \& Cheever, K.H. (2008). Textbook of Medical Surgical Nursing. 12 ed Philadelphia: Lippincott Williams \& Wilkins.

Sugiyono, (2013). Metode Penelitian Kuantitatif Kualitatif dan R \& D. Cetakan Ke-18. Bandung: Alfabeta

Sumiar, (2005). Pengalaman Pasien GGK yang menjalani Hemodialisis, diambil pada tanggal Oktober 2014 dari: www.akademik.unsri.ac.id

Suwitra, K., (2006). Penyakit Ginjal Kronik. Dalam Sudoyo, dkk. Buku Ajar IImu Penyakit Dalam. Jakarta: Pusat Penerbitan Departemen Penyakit Dalam Fakultas Kedokteran Universitas Indonesia

Syamsiah, N., (2011). Faktor-Faktor Yang Berhubungan Dengan Kepatuhan Pasien Ckd Yang Menjalani Hemodialisa di RSPAU Dr. Esnawan Antariksa Halim Perdana Kusuma Jakarta, Tesis, Jakarta: Universitas Indonesia. 